\title{
Üniversite Öğrencilerinin Reaksiyon Hızı ve Kimyasal Denge Konusundaki Bilişsel Yapılarının İncelenmesi
}

\section{Examination of Undergraduates' Cognitive Structures on Reaction Rates and Chemical Equilibrium}

\author{
Şenol ŞEN ${ }^{1}$, Lütfiye VAROĞLU², Ayhan YILMAZ ${ }^{3}$ \\ • Geliş Tarihi: 06.07.2018 • Kabul Tarihi: 21.11.2018 • Yayın Tarihi: 01.01.2019
}

\section{$\ddot{O} z$}

Bu çalışmanın amacı üniversite öğrencilerinin reaksiyon hızı ve kimyasal denge konuları ile ilgili bilişsel yapılarını Kelime İlişkilendirme Testi (KİT) ile belirlemek ve kelime ilişkilendirme testi sonuçları ile açık uçlu soruların sonuçları arasındaki ilişkiyi incelemektir. Çalıșma, bir vakıf üniversitesinde beslenme ve diyetetik lisans programında, Genel Kimya II dersi kapsamında, birinci sınıfa devam eden 77 öğrenci ile yürütülmüştür. Veri toplama aracı olarak, reaksiyon hızı ve kimyasal denge konuları ile ilgili araştırmacılar tarafından hazırlanmış olan açı uçlu sorular ve kelime ilişkilendirme testi kullanılmıştır. Öğrencilerin bilişsel yapılarının ortaya çıkartılmasında kesme noktası yönteminden yararlanılmıştır. Verilerin analizinde; içerik analizi, Kruskal Wallis testi ve korelasyon analizi kullanılmıştır. Çalışmanın sonunda, öğrencilerin KİT toplam puanları ile açık uçlu sorulardan aldıkları toplam puanlar arasında yüksek düzeyde anlamlı bir ilişkinin olduğu bulunmuştur. Kruskal Wallis testi sonuçlarına göre, altı farklı bilgi düzeyine göre gruplandırılmış öğrencilerin KİT toplam puanları arasında anlamlı bir farklılık olduğu tespit edilmiştir. Sonuç olarak, kelime ilişkilendirme testlerinin öğrencilerin bilişsel yapılarının ortaya çıkarılmasında alternatif bir değerlendirme aracı olarak kullanılabileceği söylenebilir.

Anahtar sözcükler: kimyasal denge, reaksiyon hızı, bilişsel yapı, üniversite öğrencileri.

\begin{abstract}
The aim of this study was to determine undergraduate students' cognitive structures about reaction rates and chemical equilibrium through word association test and to analyse the correlations between the results obtained in Word Association Test (WAT) and in open-ended questions. The research was conducted in a foundation university within the framework of General Chemistry II course with the participation of 77 first year students at the nutrition and dietetics department. Open-ended questions and word association test about the subjects of reaction rates and chemical equilibrium prepared by the researchers were used as data collection tools. The method of cut-point was employed in revealing students' cognitive structures. Content analysis, Kruskal Wallis test and correlation analysis were used to analyse the data. Consequently, it was found that there were high-level significant correlations between students' total WAT scores and the total scores they had received from open-ended questions. Significant differences were found between students' total WAT scores according to Kruskal Wallis test results at six different levels of knowledge. As a result, it may be said that word association test can be used as an alternative assessment tool in revealing students' cognitive structures.
\end{abstract}

Keywords: chemical equilibrium, reaction rate, cognitive structure, undergraduates.

\section{Önerilen Atıf Bilgisi:}

Şen, Ş., Varoğlu, L. ve Yılmaz, A.(2019). Examination of undergraduates' cognitive structures on reaction rates and chemical equilibrium. Pamukkale Üniversitesi Eğitim Fakültesi Dergisi, 45, 335-352.

\footnotetext{
1 Doç. Dr., Hacettepe Üniversitesi, Eğitim Fakültesi, ORCID: 0000-0003-3831-3953, schenolschen@gmail.com

${ }^{2}$ Doktora Öğrencisi, Lefke Avrupa Üniversitesi, Eczacılık Fakültesi, ORCID: 0000-0003-2595-5746, lvaroglu@eul.edu.tr

3 Prof. Dr., Hacettepe Üniversitesi, Eğitim Fakültesi, ORCID: 0000-0003-4252-5510, ayhany@,hacettepe.edu.tr
} 


\section{Introduction}

Chemistry is a branch of science involving several intangible subjects and concepts. Understanding those subjects necessitates students' understanding the relevant concepts and ideas- that is to say; their developing coherent and consistent knowledge structures (Burrows \& Mooring, 2015). It was found in the literature that many students were inadequate in conceptual understanding of the basic subjects of chemistry (Banerjee, 1991; Hackling \& Garnett, 1985; Nakhleh, 1993; Nakhleh \& Mitchell, 1993). Therefore, it is important for science education researchers to determine cognitive structures in order to understand how learners obtain and structure knowledge (Tsai \& Huang, 2002). Educators and scientists supporting cognitive philosophy tried to represent what individuals learn in "cognitive structures" (Tsai \& Huang, 2001). Cognitive structures are the theoretical structures indicating the concepts in long-term memory and the relations between those concepts (Shavelson, 1974). It can also be defined as structures containing the current experiences and knowledge, which will lead and shape the process of processing information and reconstructing it depending on stimulus (Tsai \& Huang, 2002). According to constructivist paradigm, knowledge is structured by individuals. Therefore, students in the same learning environment can develop different cognitive structures and different ways of organizing scientific knowledge even if the knowledge offered and the learning conditions are the same (Tsai \& Huang, 2002). For this reason, determining cognitive structures will help educators in determining misconceptions and learning difficulties and in improving learning processes (Jonassen, 1987; Snow, 1989; Tsai \& Huang, 2002). Analysing the cognitive structures, what learners know can be assessed (Tsai, 2001).

Determining students' cognitive structures can contribute to both teachers and students in positive ways. While it helps teachers to arrange learning process and learning environment, it supports students in improving abilities to assure more self-directed learning. Besides, determining students' cognitive structures will also help teachers to analyse students' prior knowledge and thus help students to develop more appropriate learning strategies to be more successful at courses and to have more meaningful learning output. On the other hand, analysing students' cognitive structures can give teachers the opportunity to assess what students learn in the teaching process. On considering it from the perspective of metacognitive learning, determining students' cognitive structures facilitates conceptual change and conceptual development (Tsai \& Huang, 2002).

Traditional pencil and paper tests are used in evaluating students' knowledge about certain subjects. However, educators cannot reach adequate knowledge about the associations between concepts in students' mind and about how they establish those associations and how they organize knowledge in this way. Therefore, analysing cognitive structures will be an important indicator in assessing students' knowledge (Tsai, 2001). In this context, alternative methods of measurement and evaluation exhibiting students' cognitive structures and the ties between concepts in those structures, also helps to find whether or not the associations between the concepts are adequate have gained importance (Bahar, Nartgün, Durmuş, \& Biçak, 2006). Various techniques are used in determining cognitive structures. Methods such as word association tests (Gunstone, 1980), concept maps (Novak \& Gowin, 2006) and flow maps (Anderson \& Dimetrius, 1993) were used for this purpose. 
Gunstone (1980) points out that word associations tests (WAT) were first recommended by Johnson (1967) in the 1960s. Through time, they were used in science education research as instruments helping to determine and to map the concepts students have including the relations between knowledge and cognitive structures (Bahar, 2003; Cachapuz, \& Maskill, 1987; Bahar \& Özatl1, 2003; Derman \& Eilks, 2016; Johnstone \& Moynihan, 1985; Bahar, Johnstone \& Sutcliffe, 1999). Word association is a technique designed to uncover the associations students establish between concepts. It is a technique used in analysing students' cognitive structures and the ties between concepts in those structures and in finding whether or not the associations between concepts in the long-term memory are adequate and meaningful. In this technique, students give the words a key concept related to a subject associate as answers in a certain time limit (usually 30-50 seconds, according to age group). According to the number and type of responses individuals give to the key words, interpretation can be made as to whether they have understood a subject fully or not (Bahar, 2003; Bahar et al., 1999; Bahar \& Özatl1, 2003; Derman \& Eilks, 2016).

Since students generally have difficulty in understanding chemical events (Barke, Hazari, \& Yitbarek, 2009), they may not have adequate knowledge about many subjects of chemistry (Kavanaugh \& Moomav, 1981). The subjects of reaction rates and chemical equilibrium are also the subjects, which are not meaningfully learnt by students. Because these subjects contain partially intangible concepts, that are difficult for both teachers and students to understand (Justi, 2002; Quilez-Pardo \& Solaz-Portoles, 1995). Studies concerning reaction rates and chemical equilibrium found that students had misconceptions about both subjects (Banerjee, 1991; Cheung, 2009; Çakmakçı, Leach, \& Donnelly 2006; Hackling \& Garnett, 1985; Nakhleh, 1992; Kolomuc \& Tekin, 2011; Quilez-Pardo \& Solaz-Portoles, 1995). Understanding reaction rate and the factors influencing to the reaction rate are important in learning chemistry (Cachapuz \& Maskill, 1987). Moreover, the reaction rate is the topic that can also be considered to be a prerequisite for learning the subject of chemical equilibrium (Kaya \& Geban, 2012). Therefore, students' inadequacy in the subjects of reaction rate and chemical equilibrium hinders learning other subjects of chemistry. Thus, determining students' cognitive structures about the subjects of reaction rate and chemical equilibrium will contribute significantly to the literature and educators. A review of literature showed that, word association tests were frequently used in recent years so as to determine students' cognitive structures (Bingöl, 2017; Derman \& Eilks, 2016; Nakiboğlu, 2017; Turan \& Erdoğan, 2017; Yücel \& Özkan, 2015). The review also demonstrated that, word association tests were used in determining high school students' cognitive structures about the subjects of chemical equilibrium and reaction rate (Gussarsky \& Gorodetsky, 1990; Liu, 2004; Şendur \& Toprak, 2017). Yet, the review demonstrated that no studies analysing university students' cognitive structures about reaction rates and chemical equilibrium were elaborate. Therefore, this study aims to investigate undergraduates' cognitive structures about reaction rates and chemical equilibrium issues that have a significant role for basic chemistry course in undergraduate programmes in first year of university. By this way, the study aims to determine what university students combine and associate in their mind in relation to reaction rate and chemical equilibrium. The results will provide educators with important clues in arranging learning environments and in precautions to be taken. Besides, this study uses word association test, one of alternative evaluation instruments, in addition to open-ended questions and makes a 
comparison in determining students' levels of knowledge about reaction rate and chemical equilibrium. In accordance with its purpose, our study will be guided by the following research questions:

1. How do students' total scores for open-ended questions and WAT distribute?

a. What is the total number of words that students use for each concept in WAT?

b. What is the most given answer by the students to the key words in WAT?

2. How are the cognitive structures of the students about reaction rates and chemical equilibrium topics?

3. Is there a significant correlation between scores received from WAT evaluation and open-ended questions?

4. Is there a significant correlation between students' total WAT scores and total number of words that they used as answers to WAT?

5. How do students' levels of achievement distribute according to their total WAT scores?

\section{Method}

\section{Research Model}

In the present study, a case study that is one of the qualitative research methods was utilized. Case study is a research method that is based on the questions of how and why and which makes it possible to investigate in-depth within its natural real life framework a phenomenon or an event that researchers cannot control (McMillan, 1996; Patton, 1990; Yıldırım \& Şimşek, 2011).

\section{Study Group}

The study was carried out through the General Chemistry II compulsory course in the spring semester of the 2017-2018 academic year. The participants of the study were 77 students (55 females and 22 males) whose was a volunteer and attend the nutrition and dietetics department of a foundation university. The participants were take the course of General Chemistry I, which has topics such as; matter and measurements, structure of atom, the periodic table, chemical compounds, chemical reactions, intermolecular forces and gas laws in the fall semester of the 2017-2018 academic year. The participants were briefed on five weeks (two hours in a week) the reaction rate and chemical equilibrium topics by the lecturer, then the data was collected. The participants were 67 first and 10 second year students whose ages ranged between 18 and 22 (average 21), and their cumulative grade point average (CGPA) ranged between 1.05 and 3.70 (average 2.30) over 4 .

\section{Data Collection Tool}

\section{Reaction rate and chemical equilibrium knowledge test}

There were seven open- ended questions which prepared by the researchers; three of the questions were about reaction rate and four of them were about chemical equilibrium topics. Expert opinion was consulted to assure that the open-ended questions were parallel to word association test for content validity. The researchers evaluated the open-ended questions 
together. Agreement between raters was taken into consideration in marking the responses to the open-ended questions, and the final decision was made together. An example for each of the subjects of reaction rate and chemical equilibrium is given below:

1) For the rate equation of reaction below;

$2 \mathrm{NO}(\mathrm{g})+\mathrm{Cl}_{2}(\mathrm{~g}) \rightarrow 2 \mathrm{NOCl}(\mathrm{g})$

The overall order of reaction is 3 , with respect to $\mathrm{NO}$ is 2 and with respect to $\mathrm{Cl}_{2}$ is 1 .

When 0.04 mole $\mathrm{NO}$ and 0.04 mole $\mathrm{Cl}_{2}$ placed in $2 \mathrm{~L}$ container, compare the initial rate with:

a) The reaction rate at the moment when half of $\mathrm{NO}$ is consumed,

b) The reaction rate at the moment when $1 / 4$ of $\mathrm{Cl}_{2}$ is consumed,

c) The reaction rate when half of $\mathrm{Cl}_{2}$ is consumed.

2) For the equilibrium of;

$\mathrm{CO}_{2}(\mathrm{~g})+\mathrm{H}_{2}(\mathrm{~g}) \leftrightarrow \mathrm{CO}(\mathrm{g})+\mathrm{H}_{2} \mathrm{O}(\mathrm{g})$

If the equilibrium constant is $\mathrm{K}=0.08$ at $400{ }^{\circ} \mathrm{C}$, and $\mathrm{K}=0.41$ at $600{ }^{\circ} \mathrm{C}$; is the reaction exothermic or endothermic?

\section{Word association test}

The subjects of reaction rate and chemical equilibrium, which are the subject matter of this research, are among the subjects of General Chemistry II course. Word association test containing the key words; Le Chatelier principle, activation energy, chemical equilibrium, equilibrium, reaction rate, rate constant, equilibrium constant and reversible was used to reveal students' cognitive structures about the subjects. The students were informed of WAT prior to data collection thinking that they did not have any information about it, and then an implementation was made in relation to the subject of chemical bonds which was selected from general chemistry.

\section{Data Analysis}

Students' responses to the key concepts in the word association test were analyzed by using content analysis, and obtained frequency table shown in Appendix 1. Bahar et al. (1999) point out that network of concepts can be created through cut off point technique based on frequencies and thus students' cognitive structures can be revealed. Setting out from this point, cut off points were determined in this study at six levels by considering the frequency values: (1) cut-off point 40-58, (2) cut-off point 30-39, (3) cut-off point 20-29, (4) cut-off point 10-19, (5) cut-off point 6-10 and (6) cut-off point 1-5.

At the second stage of the study, students' responses to each key concept were analyzed in WAT marking and the total scores for WAT were calculated. The total scores are found by giving, 5 points to answer if it is closely associated with key concepts, 4 points if it is indirectly associated, 3 points if it is an examples, 2 points if it is a repeated example, 1 point if it is unrelated and 0 point for no answers (Karslı Baydere, 2017). 
On the other hand, the open-ended questions about reaction rate and chemical equilibrium topics, were assessed according to a rubric prepared by the researchers. Marking differences between all three raters were taken into consideration and thus final decision was made about marking.

\section{Findings}

The research findings were analyzed in accordance with the sub-problems of this study. Table 1 shows total number of words that students use for each concept in the word association test and reveal the most given answer to the key words.

Table 1. Total Student Response Word Frequencies

\begin{tabular}{|c|c|c|c|c|c|}
\hline $\begin{array}{l}\text { Stimulus } \\
\text { words }\end{array}$ & $\begin{array}{l}\text { Number of } \\
\text { words (f) }\end{array}$ & $\begin{array}{c}\text { Number of } \\
\text { words } \%\end{array}$ & $\begin{array}{c}\text { The most written } \\
\text { response }\end{array}$ & $\begin{array}{c}\text { Number of } \\
\text { most written } \\
\text { response }\end{array}$ & $\begin{array}{c}\text { The most } \\
\text { written } \\
\text { response \% }\end{array}$ \\
\hline Equilibrium & 539 & 20.2 & Equal & 45 & 17.5 \\
\hline Le Chatelier & 401 & 15.0 & Temperature & 48 & 18.7 \\
\hline $\begin{array}{l}\text { Activation } \\
\text { energy }\end{array}$ & 293 & 11.0 & $\begin{array}{c}\text { Activation } \\
\text { Energy }\end{array}$ & 19 & 7.4 \\
\hline $\begin{array}{l}\text { Chemical } \\
\text { Equilibrium }\end{array}$ & 340 & 12.7 & Concentration & 14 & 5.5 \\
\hline Reaction Rate & 304 & 11.4 & Concentration & 27 & 10.5 \\
\hline Rate constant & 280 & 10.5 & Concentration & 23 & 8.9 \\
\hline $\begin{array}{l}\text { Equilibrium } \\
\text { constant }\end{array}$ & 268 & 10.0 & $\begin{array}{l}\text { Concentration of } \\
\text { Reactant/product }\end{array}$ & 23 & 8.9 \\
\hline Reversible & 246 & 9.2 & Reversible & 58 & 22.6 \\
\hline Total & 2671 & 100 & & 257 & 100 \\
\hline
\end{tabular}

Students' cognitive structures about the subjects of reaction rates and chemical equilibrium were analyzed based on frequencies found in consequence of WAT. Concept networks that created with cutoff point technique are shown in Figure 1.

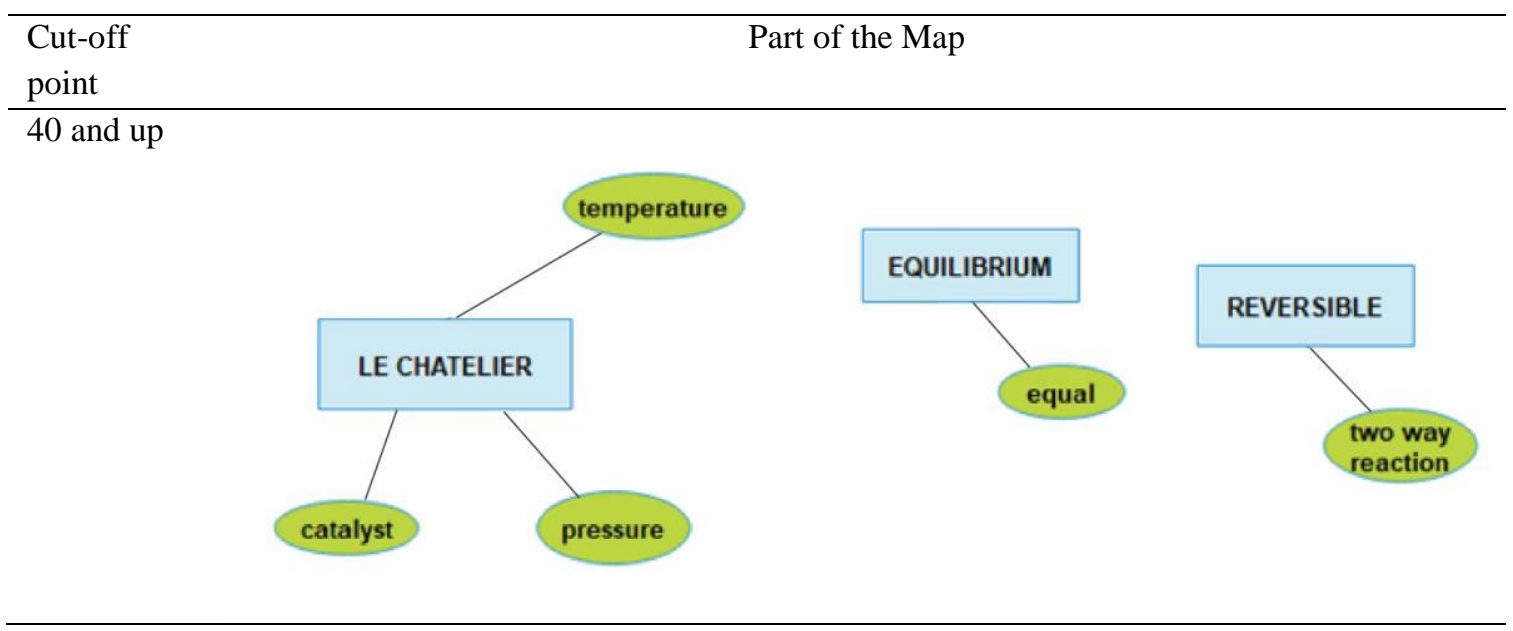


Üniversite Öğrencilerinin Reaksiyon Hızı ve Kimyasal Denge Konusundaki Bilişsel Yapılarının İncelenmesi

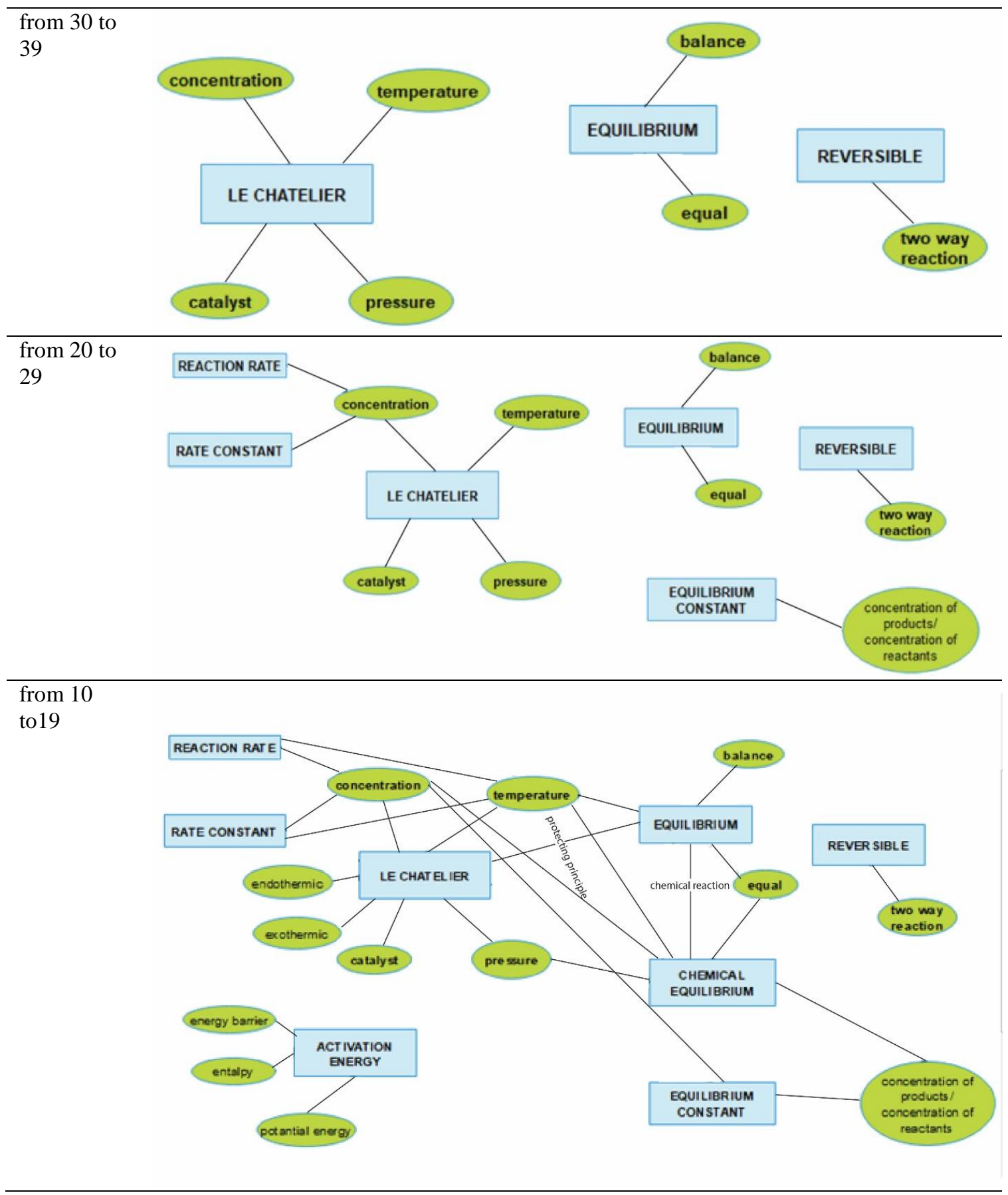




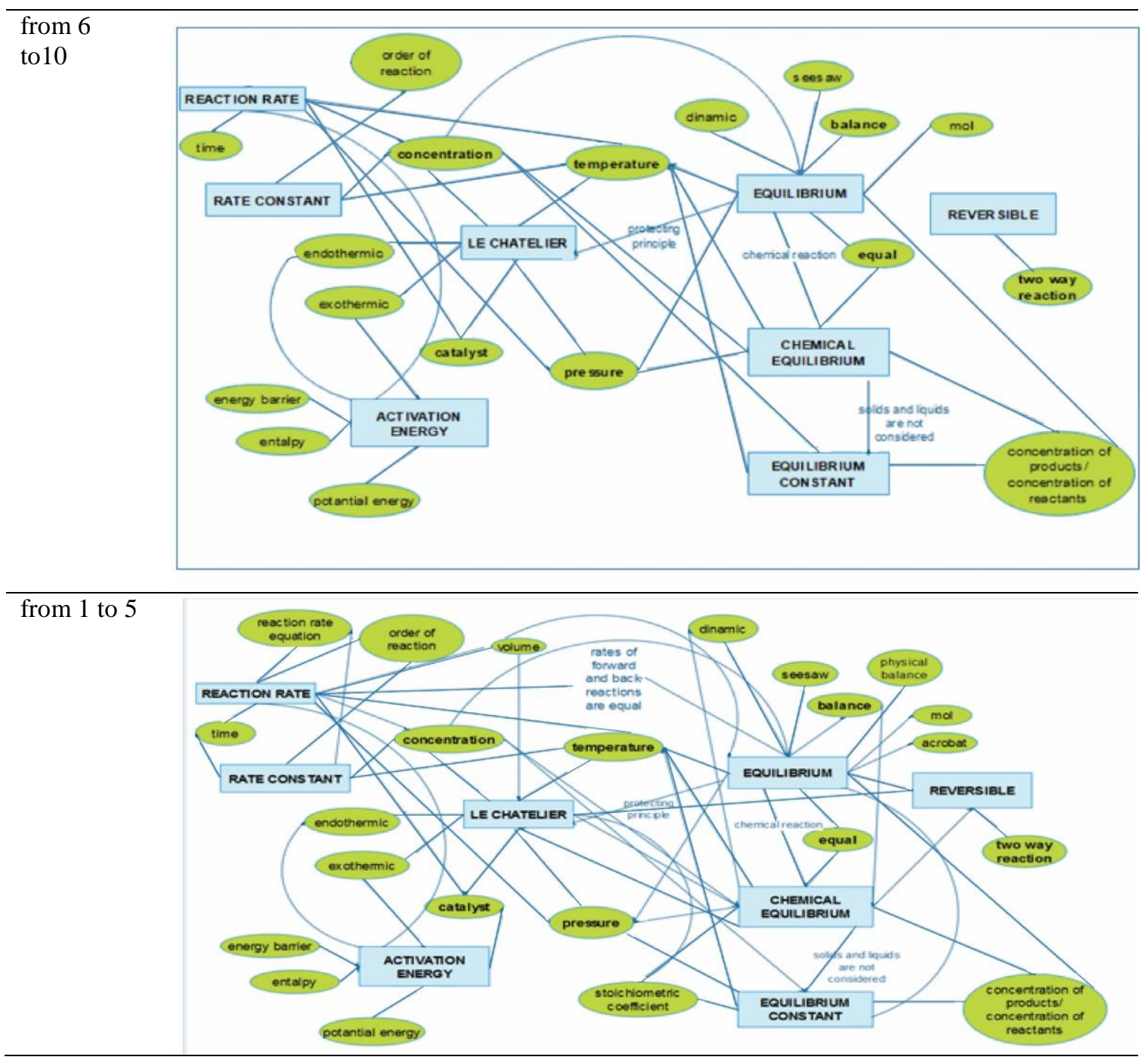

Figure 1. Cognitive structures of the students according to the frequencies

The model shown in Figure 2, was created by considering the frequencies of students' responses to the relevant key concepts, so as to reveal the students' cognitive structures. Figure 2 indicates the students' conceptual structures about the subjects of reaction rate and chemical equilibrium. The model indicates that; key concepts has common responses. The model was constructed in a manner as to be closer to the key concept for which response word is repeated the most. 


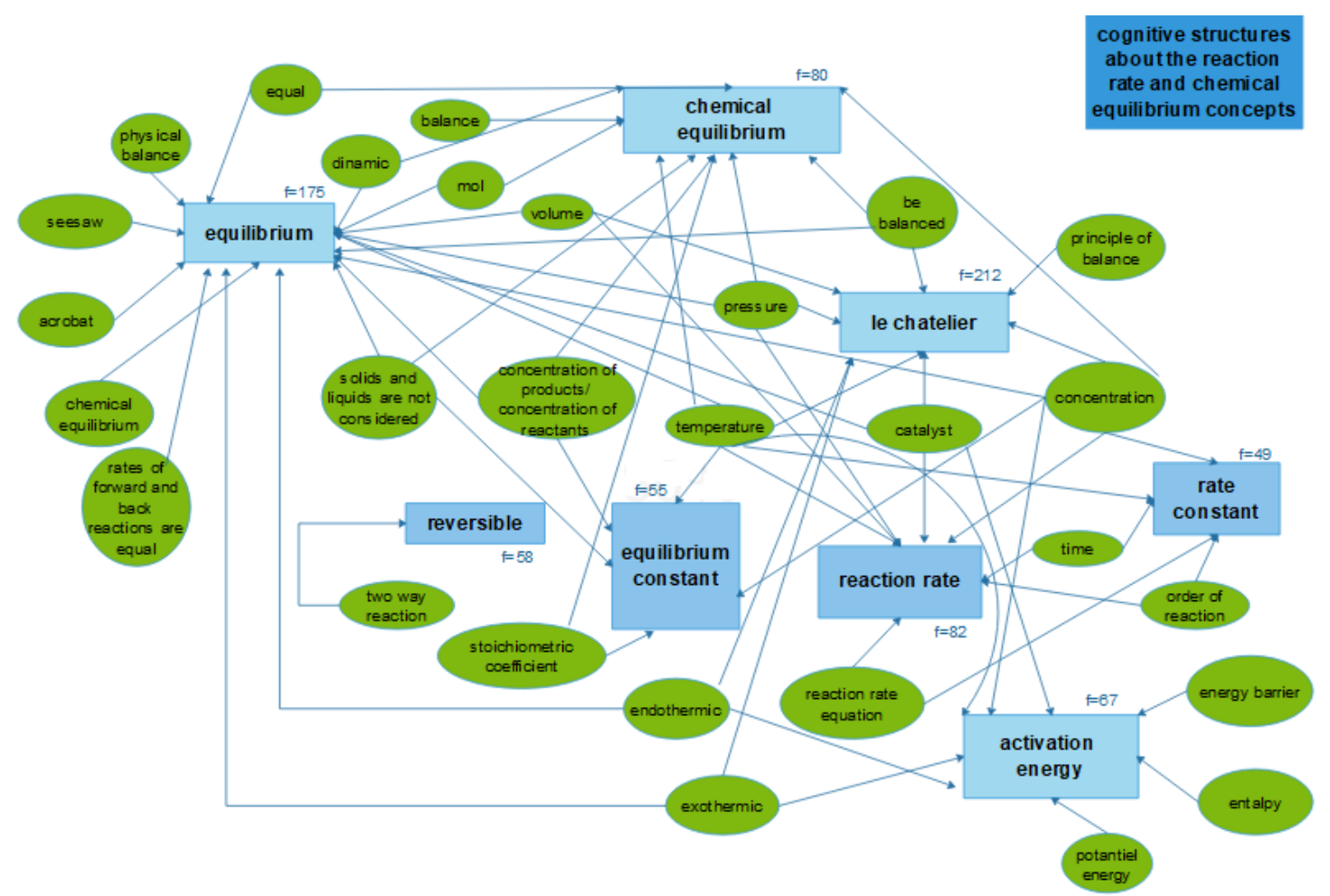

Figure 2. Cognitive structures of the students about the reaction rate and chemical equilibrium concepts

In relation to the third research question, correlation analysis was performed to examine the correlation between scores from total WAT and open-ended questions, and total number of words for each key concept in the WAT. In consequence of the correlation analysis, high level, positive and significant relations between scores from total WAT and open-ended questions were found $(\mathrm{r}=0.743, \mathrm{p}<.01)$. In addition, weak and significant correlations were found between total WAT scores and total number of words as responses to the key words $(r=0.392, p<.01)$.

In conclusion, the study to aims to construe how students' levels of achievement distributed according to their WAT scores. The cut-off point technique, which suggested by Bahar et al (1999), researchers start with the key concepts given in WAT having the highest frequency of response word numbers and they move down respectively, to reach more general map. 6 cut-of points were determined according to response word frequencies in this study. For this reason, WAT total scores were also divided into 6 levels $(0-29,30-59,60-89,90-119,120-$ 149, 150-179) and thus classified. The number of students at each level is shown in Table 2.

Table 2. Distribution of Knowledge Levels According to Cut-off Points

\begin{tabular}{cccc}
\hline Knowledge Levels & Score interval & Number of students & $\%$ \\
\hline 1 & $0-29$ & 22 & 28.6 \\
\hline 2 & $30-59$ & & \\
3 & $60-89$ & 27 & 35.1 \\
4 & $90-119$ & 11 & 14.3 \\
5 & $120-149$ & 5 & 14.3 \\
6 & $150-179$ & 1 & 6.5 \\
\end{tabular}


Table 2 shows that $28.6 \%$ of the students had level one (the lowest level) achievement whereas $1.3 \%$ had level six (the highest level) achievement. The six levels which were determined through cut-off point technique are thought to reflect students' levels of achievement. Kruskal Wallis test was used investigate if there were any significant differences between the achievement levels. Kruskal Wallis test is used in determining whether or not there are any differences between averages of more than two groups (Büyüköztürk, 2013). Following the analysis, it was found that there were significant differences between groups $\left(\chi^{2}(\mathrm{df}=5\right.$, $\mathrm{n}=77)=70.53, \mathrm{p}<.05)$.

\section{Conclusions and Discussion}

This study aimed to uncover university students' cognitive structures about reaction rate and chemical equilibrium, which were among the important subjects of chemistry with word association test. The concepts students had formed in their mind and the associations between the concepts were revealed by means of stimulus words given by the researchers. The model containing the concept networks uncovered through cut-off point technique and students' cognitive structures about both subjects is reflective of the cognitive structures of students who are at several six levels of knowledge. Different studies revealing students' cognitive structures by using cut-off point technique are also available in the literature (Altıntaş, Kabaran, \& Kabaran, 2018; Bahar et al., 1999, Bahar \& Özatl1, 2003, Özatlı \& Bahar, 2010, Ercan, Taşdere \&Ercan, 2010, Işı1klı \& Göz, 2011, Demircioğlu et al., 2012).

Students at level one revealed equilibrium was only an equation and the Le Chatelier principle was related to heat, catalyst and pressure. Maskill and Cachapuz (1989), using word association test in relation to the subject of chemical equilibrium, state that responses such as equation, equal, immobile, identical given for the key word equilibrium express static balance. Students at level two point out about the state of balance on the scales and the concentration also influential through the Le Chatelier principle. Students at level three stated that concentration influenced rate constant and reaction rate besides that equilibrium constant was the rate of product and reactant concentration. Köseoğlu and Tümay (2015) indicate that the thought about there are no relation between activation energy and the potential energy of particles was a common misconception. The analyses demonstrated that students could not set up the association between activation energy and potential energy until level four. The associations between equilibrium and equilibrium constant and between heat and pressure could not be stated until level three; barely were they stated at level four and later. In a similar vein, Wilson (1994) also states that students at lower level could not set up the connections between such concepts as equilibrium, equilibrium constant and such variables as heat, pressure and volume; only the students at higher levels could set up those connections.

Students at level four said that activation energy was the amount of threshold energy necessary for reaction to occur; furthermore, they talked of the effects of Le Chatelier principle on endothermic and exothermic reactions and also stated that concentration was influential in equilibrium constant. In addition, students at level four also used the statement "principle preserving equilibrium" for the key word Le Chatelier. It may be concluded from this point that in students' understanding, when an external influence is applied to a system, which is at equilibrium according to Le Chatelier principle, the equilibrium progresses in a way that 
tolerates the influence. Le Chatelier principle is a conceptual tool used in predicting the changes occurring in equilibrium while changing pressure, volume or mass (Quilez, 2004).

Students at level five associated reaction rate with order of reaction and time also they made statements indicating that solids and liquids concentrations were not taken into consideration in equilibrium, that equilibrium had a dynamic structure, that equilibrium constant was influenced by concentration and by heat and that activation energy was associated with reaction rate. Kousathana and Tsaparlis (2002) explain that students had misconceptions about heterogeneous equilibrium and they included concentrations of the solid substances outside the phase at which reaction occurred in equilibrium equation statement. Köseoğlu and Tümay (2015) state that students think that a system will stop when it reaches equilibrium due to their thought that chemical equilibrium is a static and two-directional event; and thus the researchers say that students do not fully understand the dynamic nature of equilibrium. Cachapuz and Maskill (1989) say based on students' responses to the WAT that some of the students do not understand the real importance of the system of chemical equilibrium.

Students at level six described the point at which reaction rates forward and backward were equal as chemical equilibrium, and they said that chemical equilibrium was expressed through relations between heat and activation energy and through reversible reactions. Karpudewan, Treagust, Mocerino, Won and Chandrasegaran (2015) reflect that Le Chatelier principle is misleading due to the vagueness in the statement "a system slides towards the direction where it diminishes the effect when an external effect is applied to the system, which is in balance according to the rule of Le Chatelier". In a study investigating misconceptions related to Le Chatelier principle, Quilez-Pardo and Solaz-Portelez (1995) say that equilibrium constant is rarely used in explaining the chemical equilibrium shift. In a similar way, on examining conceptual networks, it was found that students could not set up associations between equilibrium constant and Le Chatelier principle. Students of this level were found to give such response words as seesaws and acrobats in relation to equilibrium. Similarly, Köseoğlu and Tümay (2015) predicate students try to explain chemical equilibrium through physical balance approach and thus they have misconceptions. Maskill and Cachapuz (1989) indicate that giving examples such as acrobats and see-saws, which are thought to be normally in balance at physics classes, in relation to a superficially unchanging aspect of a chemical system which is in balance helps to reinforce the thought of static equilibrium.

It is pointed out in the model reflecting the cognitive structures about the topics of reaction rate and chemical equilibrium (Figure 2) that students can set up associations between chemical equilibrium, equilibrium and Le Chatelier principle. In addition to that, while students associate Le Chatelier principle with chemical equilibrium, they associate reversible with both equilibrium and chemical equilibrium. Students were found to associate the concept of concentration most with Le Chatelier principle and then with equilibrium, chemical equilibrium, equilibrium constant, reaction rate and rate constant. It was also seen in the model that the concept of catalyst was associated with activation energy and reaction rate. Apart from that, equilibrium constant was associated not only with chemical equilibrium but also with the concept of equilibrium whereas product/reactant concentration- (which was the representation of equilibrium constant) was associated with equilibrium, equilibrium constant and chemical equilibrium. Gussarsky and Gorodetsky (1988) import that WAT is an instrument, which may 
be used in monitoring the learning of the content and nature of the concept of chemical equilibrium.

High positive correlations between WAT total scores and scores for knowledge test demonstrated that WAT was reflective of students' achievement. Johnstone and Moynihan (1985) found positive correlations between chemistry achievement test and word association test performance. Accordingly, Bahar and Özatlı (2003) point out that there are positive correlations between the number of words as response to the WAT and exam achievement. The study also concludes that total WAT scores have weak correlations with the total number of words written in the WAT. It was found that students at low level of achievement left answers empty in the traditional assessment tool while they wrote words close in number to the ones written by students at high level of achievement in WAT. It is believed that students with low achievement can state their thoughts with the key words better in WAT than they do with openended questions in knowledge test thus consequently their incomplete knowledge and misconceptions can be revealed more easily. However, Nakiboğlu (2008) states that students' tendency to repeat the words with similar meanings is a restriction of WAT.

Students' cognitive structures were revealed with the help of cut-off point technique. By this way, the students were divided into 6 levels with this technique. The results of Kruskal Wallis test were also in parallel to the concept networks, and it may be concluded that the cutoff points separated the levels of students since the knowledge levels of students at these 6 levels differed significantly in the subjects of reaction rate and chemical equilibrium. The fact that more than half of the students were at the first three levels indicated that their knowledge about the subjects was inadequate. Studies in the literature also obtained similar results (Banerjee, 1991; Cheung, 2009; Çakmakç1, Leach, \& Donnelly 2006; Hackling \& Garnett, 1985; Nakhleh, 1992; Kolomuc \& Tekin, 2011; Quilez-Pardo \& Solaz-Portoles, 1995). Researchers who are to analyse cognitive structures about the subjects of reaction rate and chemical equilibrium in the future could use the stimulus words used in this study, or they can also develop new stimulus words to test the benefits of WAT.

This current study used word association tests to find what students associated subjects of reaction rates and chemical equilibrium with in their mind. In light of above findings, word association tests could be used as an alternative measurement and evaluation method instead of traditional methods of measurement and evaluation. WAT is a useful instrument to uncover students' cognitive structures and misconceptions. WAT can be used before and after teaching in monitoring students' development if they have prior knowledge about a subject in addition to functioning as a starting point and baseline in instructional activities (Yildirir \& Demirkol, 2018). It was also found in this study that students' cognitive structure was inadequate. Therefore, educators should take special care in this matter. Şendur and Toprak (2017) attract attention to the importance of describing cognitive structures which may affect the newly structured knowledge and of investigating the way those structures change through education. Students at low level of knowledge can state the concepts in their mind better in WAT than in traditional achievement tests. It is recommended that WAT should be used in planning the educational process targeting constructivist approach so as to be able to shed light on the mental structures of students with lower achievement at the stage of assessment. 


\section{References}

Altıntaş, S., Kabaran, G. G., \& Kabaran, H. (2018). Öğretmen adaylarının eğitim programı kavramına ilişkin bilişsel yapılarının kelime ilişkilendirme testi ile belirlenmesi. Turkish Studies, 13(4), 13971411.

Anderson, O. R., \& Demetrius, O. J. (1993). A flow-map method of representing cognitive structure based on respondents' narrative using science content. Journal of Research in Science Teaching, 30(8), 953-969.

Bahar, M. (2003). Misconceptions in biology education and conceptual change strategies. Educational Sciences: Theory \& Practice, 3(1) 55-64.

Bahar, M., Johnstone, A.H. \& Sutcliffe, R.G. (1999). Investigation of students' cognitive structure in elementary genetics through word association tests. Journal of Biological Education, 33, 134-141.

Bahar, M. \& Özatlı, S. (2003). Kelime iletişim testi yöntemi ile lise 1. sınıf öğrencilerinin canlıların temel bileşenleri konusundaki bilişsel yapılarının araştırılması. Balıkesir Üniversitesi Fen Bilimleri Enstitüsü Dergisi, 5(2), 75-85.

Bahar, M., Nartgün, Z., Durmuş, S. \& Bıçak, B. (2006). Geleneksel ve alternatif ölçme ve değerlendirme ögretmen el kitabı. Ankara: PegemA Yayıncılık.

Banerjee, A. C. (1991). Misconceptions of students and teachers in chemical equilibrium. International Journal of Science Education, 13(4), 487-494.

Barke, H. D., Hazari, A., \& Yitbarek, S. (2009). Misconceptions in chemistry: Addressing perceptions in chemical education. Berlin: Springer-Verlag.

Bingol, H. (2017). Evaluation of the cognitive structures of the middle school students about the concept of" Water Pollution" by using free word association test. Online Submission, 8(27), 249-258.

Burrows, N. L., \& Mooring, S. R. (2015). Using concept mapping to uncover students' knowledge structures of chemical bonding concepts. Chemistry Education Research and Practice, 16(1), 53-66.

Büyüköztürk, Ş. (2013). Sosyal bilimler için veri analizi el kitabı (9. Baskı). Ankara: Pegem Akademi.

Cachapuz, A. F. C. \& Maskill, R. (1987). Detecting changes with learning in the organization of knowledge: Use of word association tests to follow the learning of collision theory. International Journal of Science Education, 9(4), 491-504.

Cachapuz, A. F. C., \& Maskill, R. (1989). Using word association in formative classroom tests: following the learning of Le Chatelier's principle. International Journal of Science Education, 11(2), 235-246.

Çakmakçı, G., Leach, J., \& Donnelly, J. (2006). Students' ideas about reaction rate and its realationship with concentration or pressure. International Journal of Science Education, 28(15), 1795-1815.

Cheung, D., (2009). The adverse effects of Le Châtelier's principle on teacher understanding of chemical equilibrium. Journal of Chemical Education, 46(4), 514-518.

Demircioğlu, H., Vural, S., \& Demircioğlu, G. (2012). "React" stratejisine uygun hazırlanan materyalin üstün yetenekli öğrencilerin başarısı üzerinde etkisi. Ondokuz Mayıs Üniversitesi Eğitim Fakültesi Dergisi, 31(2), 101-144.

Derman, A., \& Eilks, I. (2016). Using a word association test for the assessment of high school students' cognitive structures on dissolution. Chemistry Education Research and Practice, 17(4), 902-913.

Ercan, F., Taşdere, A., \& Ercan, N. (2010). Kelime ilişkilendirme testi aracılığıyla bilişsel yapının ve kavramsal değişimin gözlenmesi. Türk Fen Eğitimi Dergisi, 7(2), 136-154.

Gunstone, R. F. (1980). Word association and the description of cognitive structure. Research in Science Education, 10(1), 45-53.

Gussarsky, E., \& Gorodetsky, M. (1988). On the chemical equilibrium concept: Constrained word associations and conception. Journal of Research in Science Teaching, 25(5), 319-333. 
Gussarsky, E., \& Gorodetsky, M. (1990). On the concept "chemical equilibrium": The associative framework. Journal of Research in Science Teaching, 27(3), 197-204.

Hackling, M. W., \& Garnett, P. J. (1985). Misconceptions of chemical equilibrium. The European Journal of Science Education, 7(2), 205-214.

Işıklı, M., \& Göz, A. T. N. L. (2011). Kelime ilişkilendirme testi aracılığıyla öğretmen adaylarının Atatürk İlkelerine yönelik bilişsel yapılarının incelenmesi. Uşak Üniversitesi Sosyal Bilimler Dergisi, 4(1), 50-72.

Johnson, P. E. (1967). Some psychological aspects of subject-matter structure. Journal of Educational Psychology, 58(2), 75-83.

Johnstone, A. H., \& Moynihan, T. F. (1985). The relationship between performances in word association tests and achievement in chemistry. The European Journal of Science Education, 7(1), 57-66.

Jonassen, D. H. (1987). Assessing cognitive structure: Verifying a method using pattern notes. Journal of Research \& Development in Education, 20(3), 1-14.

Justi, R. (2002). Teaching and learning chemical kinetics. In, J. K. Gilbert, O. De Jong, R. Justi, D. F. Treagust, \& J. H. Van Driel (Ed.), Chemical Education: Towards Research-Based Practice, Kluwer Academic Publishers: The Netherlands.

Karpudewan, M., Treagust, D. F., Mocerino, M., Won, M., \& Chandrasegaran, A. L. (2015). Investigating High School Students' Understanding of Chemical Equilibrium Concepts. International Journal of Environmental and Science Education, 10(6), 845-863.

Karslı Baydere, F. (2017). Kimya öğretiminde alternatif ölçme değerlendirme tekniklerinin kullanımı. Prof. Dr. Alipaşa Ayas, Prof. Dr. Mustafa Sözbilir (Ed.), Kimya Öğretimi (s. 723-750). Ankara: Pegem Akademi.

Kavanaugh, R.D. \& Moomaw, W.R. (1981). Inducing formal thought in intruductory chemistry students. Journal of Chemical Education, 58(3), 263-265.

Kaya, E., \& Geban, Ö. (2012). Facilitating conceptual change in rate of reaction concepts using conceptual change oriented instruction. Eğitim ve Bilim, 37(163), 216.

Kolomuç, A., \& Tekin, S. (2011). Chemistry teachers' misconceptions concerning concept of chemical reaction rate. Eurasian Journal of Physics and Chemistry Education, 3(2), 84-101.

Köseoğlu, F., \& Tümay, H. (2015). Fen eğitiminde yapılandırmacılık ve yeni ögretim yöntemleri. Ankara: Palme Yayıncılık.

Kousathana, M. \& Tsaparlis, G. (2002). Students' errors in solving numerical chemical-equilibrium problems. Chemistry Education Research and Practice, 3(1), 5-17.

Liu, X. (2004). Using concept mapping for assessing and promoting relational conceptual change in science. Science Education, 88(3), 373-396.

Maskill, R., \& Cachapuz, A. F. (1989). Learning about the chemistry topic of equilibrium: the use of word association tests to detect developing conceptualizations. International Journal of Science Education, 11(1), 57-69.

McMillan, J. H. (1996). Educational research: Fundamentals for the consumer. HarperCollins College Publishers.

Nakhleh, M. B. (1992). Why some students don't learn chemistry: Chemical misconceptions. Journal of chemical education, 69(3), 191.

Nakhleh, M. B. (1993). Are our students' conceptual thinkers or algorithmic problem solvers? Identifying conceptual students in general chemistry. Journal of Chemical Education, 70(1), 52.

Nakhleh, M.B., \& Mitchell, R.C. (1993). Concept learning versus problem solving: There is a difference. Journal of Chemical Education, 70(3), 190 doi: 10.1021/ed070p190 
Nakiboglu, C. (2008). Using word associations for assessing non major science students' knowledge structure before and after general chemistry instruction: the case of atomic structure. Chemistry Education Research and Practice, 9(4), 309-322.

Nakiboglu, C. (2017). Examination 8th grade students' cognitive structures about physical and chemical changes through word association test. The Eurasia Proceedings of Educational \& Social Sciences (EPESS), 7, 49-51.

Novak, J. D. \& Gowin, D. B. (2006). Learning how to learn (21st printing). New York: Cambridge University Press.

Özatlı, N. S., \& Bahar, M. (2010). Öğrencilerin boşaltım sistemi konusundaki bilişsel yapılarının yeni teknikler ile ortaya konması. Abant İzzet Baysal Üniversitesi Eğitim Fakültesi Dergisi, 10 (2), 9-26.

Patton, M. Q. (1990). Qualitative evaluation and research methods. SAGE Publications, inc.

Quilez, J. (2004). Changes in concentration and in partial pressure in chemical equilibria: Students 'and teachers 'misunderstandings. Chemistry Education Research and Practice, 5(3), 281-300.

Quilez-Pardo, J., \& Solaz-Portoles, J. J. (1995). Students' and teachers' misapplication of Le Chatelier's principle: Implications for the teaching of chemical equilibrium. Journal of Research in Science Teaching, 32(9), 939-957.

Şendur, G., \& Toprak, M. (2017). An investigation of changes in the cognitive structures of 11th grade students using the word association test: The case of chemical equilibrium. Electronic Turkish Studies, 12(17), 411-436.

Shavelson, R. J. 1974. Methods for examining representations of a subject- matter structure in a student's memory. Journal of Research in Science Teaching, 11, 231-249.

Snow, R. E. (1989). Toward assessment of cognitive and conative structures in learning. Educational Researcher, 18(9), 8-14.

Tsai, C. C. (2001). Probing students' cognitive structures in science: The use of a flow map method coupled with a meta-listening technique. Studies in Educational Evaluation, 27(3), 257-268.

Tsai, C. C., \& Huang, C. M. (2001). Development of cognitive structures and information processing strategies of elementary school students learning about biological reproduction. Journal of Biological Education, 36(1), 21-26.

Tsai, C. C., \& Huang, C. M. (2002). Exploring students' cognitive structures in learning science: a review of relevant methods. Journal of Biological Education, 36(4), 163-169.

Turan, S. B., \& Erdogan, A. (2017). Investigation of prospective mathematics teachers' conceptual structure about Limit. Journal of Research in Education and Teaching, 6(1), 397-410.

Wilson, J. M. (1994). Network representations of knowledge about chemical equilibrium: Variations with achievement. Journal of Research in Science Teaching, 31(10), 1133-1147.

Yıldırım, A., \& Şimşek, H. (2011). Sosyal Bilimlerde Nitel Araştırma Yöntemleri (8. Baskı). Ankara: Seçkin Yayıncılık.

Yıldırır, H. E., \& Demirkol, H. (2018). Revealing students 'cognitive structure about physical and chemical change: Use of a word association test. European Journal of Education Studies, 4(1), 134154.

Yücel, E. Ö., \& Özkan, M. (2015). Determination of secondary school students' cognitive structure, and misconception in ecological concepts through word association test. Educational Research and Reviews, 10(5), 660-674. 


\section{Uzun Özet}

\section{Giriş}

Reaksiyon hızı ve kimyasal denge konuları öğrenciler tarafından anlamlı olarak öğrenilemeyen konular arasında yer almaktadır. Çünkü kimyasal denge ve reaksiyon hızı konuları kısmen soyut kavramlar içerdiğinden dolayı hem öğretmenler hem de öğrenciler için anlaşılması zor konulardır (Justi, 2002; Quilez-Pardo \& Solaz-Portoles, 1995). Kimyasal denge ve tepkime hızı konularında lise öğrencilerinin bilişsel yapılarını belirlemek amacıyla kelime ilişkilendirme testlerinin kullanıldığ1 tespit edilmiştir (Gussarsky \& Gorodetsky,1990; Liu, 2004; Şendur \& Toprak, 2017). Fakat literatür incelendiğinde üniversite öğrencilerinin reaksiyon hızları ve kimyasal denge konusu ile ilgili bilişsel yapılarının incelendiği detaylı çalışmaların olmadığı tespit edilmiştir. $\mathrm{Bu}$ nedenle bu çalışmanın amacı üniversite öğrencilerinin tepkime hızları ve kimyasal denge ile ilişkili bilişsel yapıları belirlenmek istenilmiştir.

\section{Yöntem}

$\mathrm{Bu}$ çalışmada nitel araştırma yöntemlerinden biri olan durum çalışması (case study) kullanılmıştır. Çalışmaya, 2017-2018 bahar döneminde bir vakıf üniversitesinde genel kimya II dersine katılan, 55 kadın ve 22 erkek olmak üzere toplam 77 öğrenci katılmıştır.

Çalışmada veri toplama aracı olarak Tepkime Hızı ve Kimyasal Denge Bilgi Testi ve Kelime İlişkilendirme Testi kullanılmıştır. Açık uçlu sorular araştırmacılar tarafından birlikte değerlendirilmiştir. Kelime İlişkilendirme Testindeki (KİT) anahtar kavramlara öğrencilerin verdikleri yanıtlar içerik analizi ile incelenmiştir.

\section{Tartışma}

$\mathrm{Bu}$ çalışmanın amacı, üniversite öğrencilerinin kimyanın önemli konularından olan tepkime hızı ve kimyasal denge konularına ilişkin bilişsel yapılarını, kelime ilişkilendirme testi yardımıyla ortaya çıkarmaktır. Çalışmada kesme noktası tekniği ile ortaya çıkan kavram ağları ve son olarak öğrencilerin bu her iki konu ile ilgili bilişsel yapılarından oluşan model altı farklı bilgi seviyesinde olan öğrencilerin bilişsel yapılarını yansıtmaktadır.

Birinci düzeyde bulunan öğrenciler, dengenin sadece bir eşitlik olduğunu, Le Chatelier ilkesinin de sıcaklık, katalizör ve basınç ile ilişkili olduğunu belirtmektedirler. İkinci düzeydeki öğrenciler, terazideki denge konumunu ve Le Chatelier ilkesinde derişimin de etkili olduğunu belirtmektedirler. Üçüncü düzeydekiler, derişimin hız sabiti ve reaksiyon hızını etkilediğini, denge sabitinin ise giren ve ürün derişimlerinin oranı olduğunu ifade etmektedirler. Analiz sonucunda elde edilen kavram ağlarında, öğrencilerin dördüncü düzeye kadar aktivasyon enerjisi ile potansiyel enerji arasındaki ilişkiyi kuramadıkları görülmektedir.

Dördüncü düzeydeki öğrenciler, aktivasyon enerjisinin tepkimenin gerçekleşmesi için aşı1ması gereken eşik enerjisi miktarı olduğunu, Le Chatelier ilkesinin endotermik ve ekzotermik reaksiyonlarda etkisini ve derişimin denge sabitine etki ettiğini belirtmektedirler. Ayrıca öğrenciler Le Chatelier anahtar kelimesi için dengeyi koruyan ilke şeklinde ifadeler kullanmışlardır.

Beşinci seviyede yer alan öğrenciler; tepkime hızını, reaksiyon mertebesi ve zamanla ilişkilendirmiş, denge ifadesinde katı ve sıvı maddelerin derişimlerinin dikkate alınmadığını, 
dengenin dinamik yapıda bir sistem olduğunu, denge sabitinin derişim ile birlikte sıcaklıktan da etkilendiğini ve aktivasyon enerjisinin tepkime hızıyla ilişkili olduğunu gösteren ifadeler kullanmışlardır. Altıncı düzeyde yer alan öğrenciler ileriye ve geriye doğru olan tepkime hızlarının eşit olduğu noktayı kimyasal denge olarak tanımlamakta, sıcaklık ve aktivasyon enerjisi ilişkisi, tersinir reaksiyonlarla kimyasal dengenin ifade edildiğini belirtmişlerdir. Buna benzer olarak kavram ağları incelendiğinde, tüm öğrencilerin denge sabiti ve Le Chatelier ilkesi arasında bir bağ kuramadığı görülmektedir. Bu düzeydeki öğrenciler tarafından denge ile ilişkili tahterevalli veya akrobatlar gibi yanıt kelimelerin verildiği görülmektedir.

Öğrencilerin bilişsel yapıları kesme noktası ile ortaya çıkarılmıştır. Öğrenciler kesme noktası tekniği ile 6 düzeye ayrılmıştır. Yapılan Kruskal Wallis testi sonuçları da ortaya çıkan kavram ağlarıyla paralellik göstererek, bu 6 düzeydeki öğrencilerin tepkime hızı ve kimyasal denge konuları bilgi seviyelerinin anlamlı derecede farklılaşmasından kesme noktalarının ayrıca öğrencilerin seviyelerini de ayırdığı sonucuna ulaşılabilir. Öğrencilerin yarısından fazlasının belirlenen ilk üç düzeyde olması, konu ile ilgili bilgilerinin yetersiz olduğunu göstermektedir.

KİT toplam puanları ile bilgi testi puanları arasındaki yüksek pozitif yönlü ilişki, değerlendirme aracı olarak KİT'in öğrencilerin başarılarını yansıtmakta olduğunu göstermektedir. Ayrıca bu çalışmada, KİT toplam puanları ile KİT'de yazılan toplam kelime sayısının zayıf düzeyde ilişkili olduğu sonucuna ulaşılmışıdır. Geleneksel yaklaşımla hazırlanan değerlendirme aracında başarı düzeyi düşük öğrencilerin genellikle cevapları boş bırakırken, KİT'de başarı düzeyi yüksek öğrencilerin yazdığı kelime sayılarına yakın sayıda kelime yazdıkları belirlenmiştir. KİT'de başarı düzeyi düşük öğrencilerin anahtar kelimelerle ilgili düşüncelerini bilgi testindeki açık uçlu sorulara göre daha rahat ifade etmelerinin sonucunda eksik öğrenilmiş bilgiler ve kavram yanılgılarının daha kolay ortaya çıkarılabileceği düşünülmektedir.

$\mathrm{Bu}$ çalışmada üniversite öğrencilerinin tepkime hızları ve kimyasal denge ile ilişkili zihinlerinde neyi birleştirdikleri ve ilişkilendirdiklerini belirlemek için kelime ilişkilendirme testleri kullanılmıştır. Çalışma sonunda elde edilen sonuçlar geleneksel ölçme ve değerlendirme yöntemleri yerine kelime ilişkilendirme testlerinin bir alternatif ölçme ve değerlendirme yöntemi olarak kullanılabileceği belirlenmiştir. KİT öğrencilerin kavramsal yapılarının ortaya çıkartılmasına ve kavram yanılgılarının belirlenmesine kullanışlı bir araçtır. KİT, öğretmenlere yeni bir konuya başlarlarken öğretim faaliyetlerine bir başlangıç noktası ve temel olabilmesinin yanında, öğrenciler konu ile ilgili daha önceden bilgi sahibiyse gelişimlerini takip etmek için öğretim öncesi ve sonrası uygulanabilmektedir (Yildirir ve Demirkol, 2018). Yine çalışma sonunda öğrencilerin bilişsel yapılarının yeterli olmadığı belirlenmiş ve eğitimcilerin bu konularda özel bir ilgi göstermesi gerekmektedir. Şendur ve Toprak (2017), yeni yapılandırılan bilgiyi etkileyebilecek bilişsel yapıları tanımlamak ve bu yapıların öğretimle nasıl değiştiğini incelemenin önemine dikkat çekmektedirler. Çalışma sonuçlarına göre düşük bilgi düzeyindeki öğrenciler KİT'de zihinlerinde olan kavramları geleneksel başarı testine göre daha çok ifade edebilme şansı bulmaktadırlar. Yapılandırmacı yaklaşımı hedef alan eğitim süreci planlanırken, önemli bir unsur olan değerlendirme aşamasında düşük başarı gösteren öğrencilerin zihin yapılarının aydınlatılabilmesi için KİT'in kullanılması önerilmektedir. 
Appendix A: The Frequency Table Used to form the concept network

\begin{tabular}{|c|c|c|c|c|c|c|c|c|}
\hline Response word & 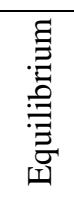 & 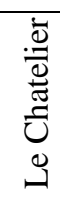 & . & 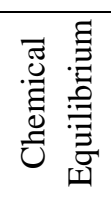 & 离 & 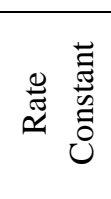 & 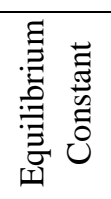 & 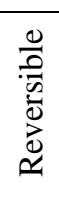 \\
\hline $\begin{array}{l}\text { Chemical } \\
\text { Equilibrium }\end{array}$ & 13 & 5 & 1 & 14 & 1 & 3 & 2 & 3 \\
\hline $\begin{array}{l}\text { Physical } \\
\text { Equilibrium }\end{array}$ & 2 & & & & & & & \\
\hline Balance & 37 & & & 2 & & & & \\
\hline Dynamic & 6 & & & 2 & & & & \\
\hline Acrobat & 4 & & & & & & & \\
\hline Seesaw & 6 & & & & & & & \\
\hline Enthalpy & & 1 & 12 & & & & & \\
\hline Equal & 45 & 1 & & 10 & & & & \\
\hline Le Chatelier & & & & 4 & & & & \\
\hline Potential energy & & & 11 & & & & & \\
\hline Concentration & 9 & 31 & 1 & 14 & 27 & 23 & 14 & \\
\hline Mole & 7 & & & 3 & & & & \\
\hline Temperature & 10 & 48 & 5 & 11 & 16 & 14 & 9 & 1 \\
\hline Pressure & 8 & 42 & 1 & 11 & 8 & 1 & 2 & 1 \\
\hline Catalyst & 3 & 41 & 3 & 2 & 9 & 2 & 3 & \\
\hline Volume & 1 & 3 & & & 1 & & & \\
\hline Protecting Principle & & 11 & & & & & & \\
\hline Rate & 5 & 1 & 6 & 2 & & 1 & 1 & 1 \\
\hline Energy barrier & & 1 & 19 & 1 & & & 1 & \\
\hline Rate Constant & 1 & & & 1 & & & & \\
\hline Equilibrium Constant & 5 & & & 4 & & & & \\
\hline Equilibrium & 3 & 10 & 1 & 9 & 1 & 2 & 2 & 4 \\
\hline Solid/Liquid & 5 & & & 2 & & & 7 & \\
\hline Reaction rate equation & 2 & & & 4 & 5 & 2 & & 1 \\
\hline $\begin{array}{l}\text { Concentration of } \\
\text { Reactant/product }\end{array}$ & 6 & 1 & & 12 & & & 23 & 2 \\
\hline Endothermic & 6 & 12 & 8 & 5 & 2 & & 2 & \\
\hline Exothermic & 5 & 12 & 8 & 4 & 2 & & 2 & \\
\hline Reversible & 4 & 1 & & 5 & 1 & & 1 & 58 \\
\hline Principle & & 12 & & & 8 & 4 & & \\
\hline Time & & & & & 8 & 4 & & \\
\hline Order of Reaction & 1 & 3 & & 1 & 8 & 6 & 1 & \\
\hline $\begin{array}{l}\text { Rates of forward reaction= } \\
\text { back reaction }\end{array}$ & 2 & & & & & & & \\
\hline Stoichiometric coefficient & 1 & 2 & & 4 & 3 & 3 & 2 & 2 \\
\hline
\end{tabular}

